\title{
Protein Kinase C Activators Block Specific Calcium and Potassium Current Components in Isolated Hippocampal Neurons
}

\author{
Diane Doerner, Thomas A. Pitler, and Bradley E. Alger \\ Department of Physiology, University of Maryland School of Medicine, Baltimore, Maryland 21201
}

Whole-cell voltage-clamp techniques were used to study the effects of the protein kinase $C$ (PKC) activators phorbol esters and $O A G$ on $\mathrm{Ca}$ and $K$ currents in differentiated neurons acutely dissociated from adult hlppocampus and in tissuecultured neurons from fetal hippocampus. PKC activators had selective depressant effects on $K$ currents, with persistent currents $\left(l_{\mathrm{K}}\right.$ and $\left.I_{\mathrm{k}-\mathrm{Ca}}\right)$ being reduced and transient current $\left(I_{A}\right)$ being unaffected.

In both cell types we recorded both high-voltage-activated, noninactivating (L-type) and high-voltage-activated, rapidly inactivating (N-type) Ca current. A low-voltage-activated, rapidly inactivating ( $T$-type) Ca current was also recorded in tissue-cultured neurons but not in acutely dissociated neurons. PKC activators markedly reduced $\mathrm{N}$-type current with less effect on L-type and no effect on T-type Ca current.

Effects of PKC activators could be reversed with washing or with application of PKC inhibitors $\mathrm{H}-7$ or polymyxin-B, an effect that could not be attributed to inhibition of CAMP. dependent protein kinase. The $\mathrm{Ca} /$ calmodulin inhibitor calmidazolium was ineffective in reversing the actions of PKC activators.

Using whole-cell voltage-clamp techniques, we have demonstrated that hippocampal neurons possess 3 distinguishable components of calcium current. Distinct $K$ currents were also observed. Our data strongly support the hypothesis that both $\mathrm{Ca}$ and $\mathrm{K}$ currents are selectively regulated by PKC and that these effects occur directly on the postsynaptic neuron.

Regulation of calcium ( $\mathrm{Ca}$ ) and potassium $(\mathrm{K})$ conductances is of central importance to a number of neurobiological issues, including control of transmitter release, mechanisms of memory and learning, and epilepsy. Recent work implicates the calciumand phospholipid-dependent protein kinase (Nishizuka, 1984), protein kinase $\mathrm{C}$ (PKC), in ionic current regulation (Baraban et al., 1985; DeRiemer et al., 1985; Alkon et al., 1986; Farley and Auerbach, 1986; Malenka et al., 1986b; Grega et al., 1987; Hammond et al., 1987; Strong et al., 1987). Although PKC is abundant in mammalian brain (Kuo et al., 1980), there is little evidence regarding details of $\mathrm{PKC}$ regulation of $\mathrm{Ca}$ and $\mathrm{K}$ conductances in brain. Central neurons probably possess multiple

\footnotetext{
Received Oct. 15, 1987; revised Mar. 7, 1988; accepted Apr. 5, 1988

This work was supported by NIH Grant NS22010 and awards from the Epilepsy Foundation of America and the McKnight Foundation. We thank Miles Research Laboratories for the gift of BAY K 8644 .

Correspondence should be addressed to Bradley E. Alger, Ph.D., Department of Physiology, University of Maryland School of Medicine, 660 W. Redwood Street, Baltimore, MD 21201.

Copyright (C) 1988 Society for Neuroscience $0270-6474 / 88 / 114069-10 \$ 02.00 / 0$
}

$\mathrm{Ca}$ as well as $\mathrm{K}$ conductances (Llinás and Yarom, 1981; Gross and Macdonald, 1987; Madison et al., 1987). While there is evidence that in some systems a noninactivating $\mathrm{Ca}$ current is influenced by PKC activation (DeRiemer et al., 1985; Rane and Dunlap, 1986), there are apparently no data regarding differential regulation of the different types of $\mathrm{Ca}$ currents in mammalian central neurons. Similarly, central neurons possess a number of $K$ conductances, and yet the effects of PKC activation have been investigated only on a few.

Phorbol esters are exogenous plant-derived compounds that can substitute for diacylglycerol, an endogenous product of phosphatidylinositol breakdown, in activating PKC (Castagna et al., 1982; Blumberg ct al., 1984; Nishizuka, 1984). We now report selective regulation of both $\mathrm{Ca}$ and $\mathrm{K}$ currents recorded under whole-cell voltage-clamp by PKC using phorbol ester and synthetic diacylglycerol (OAG) application to acutely isolated, and tissue-cultured, hippocampal neurons. Transient $\mathrm{K}$ current $\left(I_{\mathrm{A}}\right)$ was unaffected, while 2 persistent currents, Ca dependent $\left(I_{\mathrm{K}-\mathrm{Ca}}\right)$ and Ca independent $\left(I_{\mathrm{K}}\right)$, were blocked. The high-voltageactivated $\mathrm{Ca}$ currents evoked from relatively hyperpolarized potentials (L- and N-type) were depressed, while the low-voltage-activated, transient (T-type) current was unaffected. Effects of the dihydropyridines BAY K 8644 and nifedipine were consistent with the hypothesis that distinct $\mathrm{Ca}$ currents exist in these cells. All effects of PKC activators were reversible with washing or with application of the PKC inhibitors $\mathrm{H}-7$ and polymyxin-B.

\section{Materials and Methods}

Pyramidal neurons were acutely dissociated from juvenile guinea pig hippocampus according to the methods of Kay and Wong (Huguenard and Alger, 1986; Kay and Wong, 1986b). Small tissue chunks $\left(1 \mathrm{~mm}^{3}\right)$ were stirred in a buffered salt solution containing $1.8 \mathrm{mg} / \mathrm{ml}$ trypsin for $1-2 \mathrm{hr}\left(32^{\circ} \mathrm{C}\right)$, then triturated through fire-polished pasteur pipettes. In the acute preparation, fully differentiated cells are studied shortly after dissociation. They are not grown or maintained under culture conditions. Tissue-cultured hippocampal neurons were also studied in some experiments. Hippocampal tissue cultures from fetal rat were prepared according to conventional methods (Segal, 1983).

Membrane current was measured under whole-cell voltage-clamp (Hamill et al., 1981) using either an Axoclamp II (Axon Instruments) in the single-electrode continuous mode or a Dagan 8900 (Dagan Corporation). Calcium currents were recorded using low-resistance (1-2 $\mathrm{M} \Omega$ ) electrodes filled with (concentrations in $\mathrm{mM}$ ) $145 \mathrm{CsCH}_{3} \mathrm{SO}_{3}, 10$ HEPES, $5 \mathrm{MgCl}_{2}, 11 \mathrm{EGTA}, 1 \mathrm{CaCl}_{2}, 5 \mathrm{ATP}, 10 \mathrm{TEA}$, and 0.1 leupeptin (Boehringer Mannheim) ( $\mathrm{pH}$ 7.4). The pipette solution used to record potassium currents consisted of (in mM) $145 \mathrm{KCH}_{3} \mathrm{SO}_{3}, 10$ HEPES, 5 $\mathrm{MgCl}_{2}, 0.1$ EGTA, $0.05 \mathrm{CaCl}_{2}$, and 1 ATP (pH 7.4). $\mathrm{KCH}_{3} \mathrm{SO}_{3}$ and $\mathrm{CsCH}_{3} \mathrm{SO}_{3}$ were produced by titrating methanesulfonic acid (Aldrich) with $\mathrm{KOH}$ or $\mathrm{CsOH}$, respectively, until a neutral $\mathrm{pH}$ was reached. Liquid junction potentials arising from different pipette solutions were measured and compensated for. Electrode resistance, measured using the Axoclamp II bridge circuit, was approximately 2 -fold greater after rupturing the membrane patch than in the bath. Series resistance error was 
A
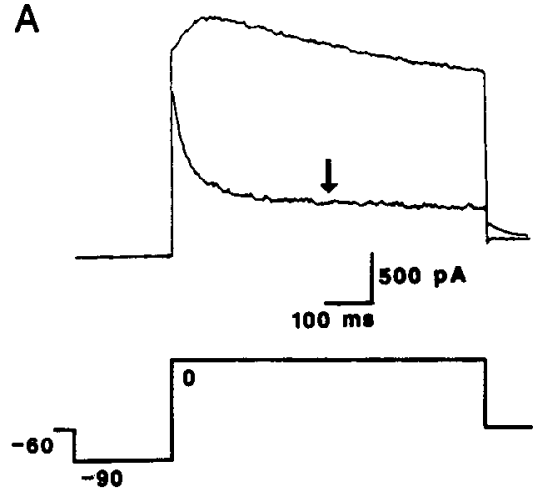

C

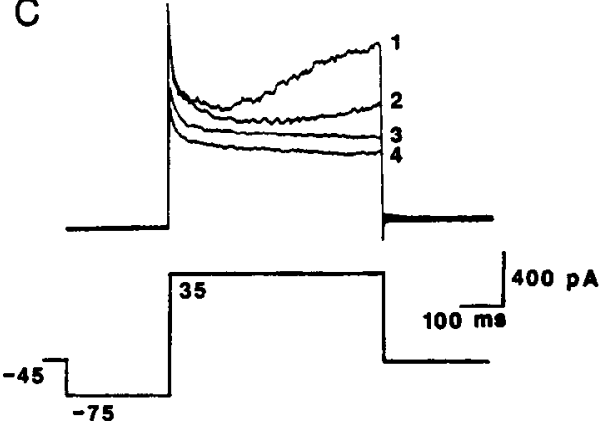

B

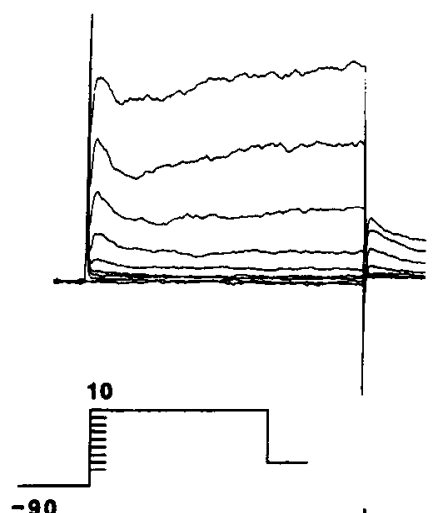

$-90$

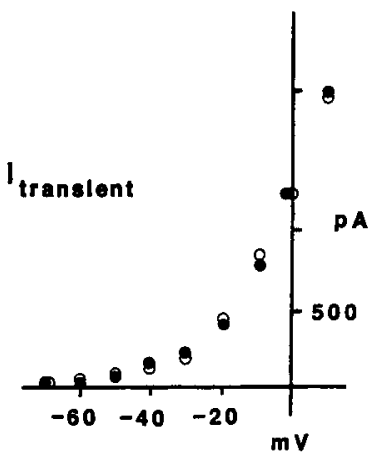

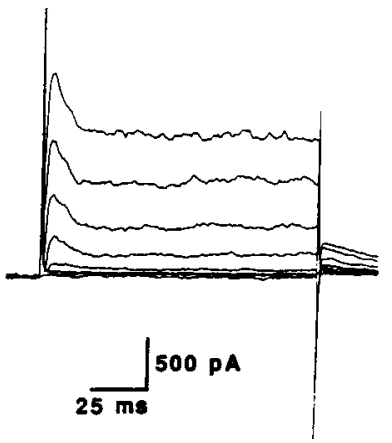

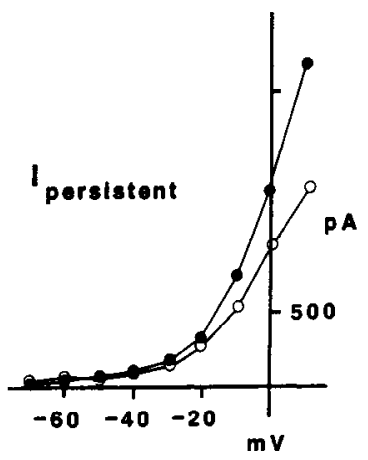

Figure 1. Activators of PKC selectively suppress persistent $\mathrm{K}$ current components in hippocampal pyramidal neurons. $A$, Outward currents evoked in an acutely dissociated neuron by a depolarizing voltage-clamp step to $0 \mathrm{mV}$ from a conditioning potential of $-90 \mathrm{mV}$, before (upper current trace) and after (arrow) bath application of $1.5 \mu \mathrm{M}$ phorbol-12,13-diacetate (PDA). PDA suppressed late outward current, unmasking a fast transient component not apparent in the control trace. Unless otherwise noted, the control solution used when recording outward currents contained (in mM) $145 \mathrm{NaCl}, 5 \mathrm{KCl}, 2 \mathrm{MgCl}_{2}, 2 \mathrm{CaCl}_{2}, 10$ glucose, 10 HEPES (pH 7.4). B. Differential effect of $1.5 \mu \mathrm{M}$ PDA on transient and persistent outward current components in an acutely dissociated neuron stepped from a conditioning potential of $-90 \mathrm{mV}$ to various depolarizing test potentials. Both transient and persistent current components were evident under control conditions. Persistent current was reduced following bath application of PDA, whereas transient current was unaffected. The $I-V$ relationship for the same neuron, measured at the peak of the transient was unchanged in PDA (filled circles, control; open circles, $1.5 \mu \mathrm{M}$ PDA). Persistent outward current, measured at the end of the depolarizing step, was reduced by PDA over the entire activation range. $I-V$ relationships were leak subtracted. $C$, Outward currents evoked in a tissue-cultured neuron by a depolarizing step to $+35 \mathrm{mV}$ from a conditioning potential of $-75 \mathrm{mV}$. Traces were recorded (1) in control saline, (2) following pressure ejection of $60 \mu \mathrm{M}$ 1-oleoyl-2-acetyl-glycerol (OAG) $(7 \mathrm{psi}, 1 \mathrm{sec})$ at the surface of the cell, (3) following recovery from OAG and after addition of $400 \mu \mathrm{M}$ $\mathrm{CdCl}_{2}$ to the bath, and (4) following a subsequent pressure ejection of $\mathrm{OAG}$ in the presence of $\mathrm{Cd}$. The discrepancy between the Ca-insensitive current blocked by OAG [difference between traces (3) and (4)] and the total current blocked by OAG [difference between (1) and (2)] is due to block of Ca-sensitive current, $I_{\mathrm{K}-\mathrm{Ca}}$.

estimated at less than $10 \mathrm{mV}$ from electrode resistance and maximal current amplitude and was uncompensated in early experiments. More recently, series resistance was compensated using the Dagan system. There was no major difference between the 2 techniques. In some cases, records were corrected for leakage current and capacitance artifacts by digital subtraction of appropriately scaled currents resulting from small $(20-30 \mathrm{mV})$ hyperpolarizing clamp steps.

The extracellular solution contained (in $\mathrm{mm}$ ) $145 \mathrm{NaCl}, 2 \mathrm{MgCl}_{2}, 10$ HEPES, 10 glucose, and 0.001-0.005 TTX (pH 7.4), and in different experiments, $5 \mathrm{KCl}, 5 \mathrm{CsCl}, 20 \mathrm{TEA}, 2-10 \mathrm{CaCl}_{2}$, and/or $2-10 \mathrm{BaCl}_{2}$. All experiments were performed at room temperature $\left(22-24^{\circ} \mathrm{C}\right)$.

Phorbol esters [phorbol-12,13-diacetate (PDA), 0.5-1.5 $\mu \mathrm{M}$; phorbol12,13-dibutyrate (PDBu), $100 \mathrm{nM}-10 \mu \mathrm{M}$; 12-deoxyphorbol,13-isobutyrate (DPB), 1-2 $\mu \mathrm{M} ; 4$ - $\alpha$-phorbol-12,13-dibutyrate (4- $\alpha$-PDBu), 500 nM-1 mM) (Sigma, L C Services)]; 1-oleoyl-2-acetyl-glycerol (OAG; 20$50 \mu \mathrm{M}$ ) (Sigma); nifedipine, $10 \mathrm{nM}-1 \mu \mathrm{M}$ (Sigma); and calmidazolium (Compound R24571), 0.5-50 $\mu_{\mathrm{M}}$ (Sigma) were dissolved in DMSO, prepared in aliquots and frozen until usc. Polymyxin-B, 10-50 $\mu \mathrm{M}$ (Sig$\mathrm{ma}$ ), and $\mathrm{H}-7$ [1-(5-isoquinolinylsulfonyl)-2-methylpiperazine], 20-100 $\mu \mathrm{M}$ (Sigma), were dissolved in water and also stored in frozen aliquots for later use. BAY K $8644(25 \mathrm{nM}-1 \mu \mathrm{M})$ was a gift of Miles Research Laboratories. Dihydropyridine derivatives were shielded from light at all times. Drugs were either added directly to the chamber or pressureejected from blunt pipettes (approximately $2 \mathrm{M} \Omega$ ) positioned $20-40 \mu \mathrm{m}$ from the cells.
Data were filtered at $1 \mathrm{kHz}$, digitized, and stored on microcomputer disk for subsequent analysis using the pClamp system (Axon Instruments). Digitized data were plotted on an HP 7470 A plotter. Experimental values are given as means \pm SEM. Two-tailed $t$ tests were used to assess the significance of differences.

\section{Results}

\section{Effects of $P K C$ activators on $K$ currents}

Bath perfusion of active phorbol esters increases both the amplitude and rate of rise of the $\mathrm{Ca}$ action potential recorded in CA1 pyramidal cells in the hippocampal slice (Baraban et al., 1985; Malenka et al., 1986b). Blockade of K conductances could cxplain the increase in spikc parameters. Indecd, with bath perfusion with $25 \mathrm{~mm}$ TEA, or recordings made with $2 \mathrm{M} \mathrm{CsCl}$ filled electrodes, we observed a reduction in the enhancement of $\mathrm{Ca}$ spike parameters by phorbol esters (not shown). These current-clamp experiments raised the possibility that phorbol esters primarily affect $\mathrm{K}$, rather than $\mathrm{Ca}$, currents; however, they are inconclusive.

To address the issue in more detail, we made whole-cell voltage-clamp recordings from hippocampal neurons acutely dis- 
A
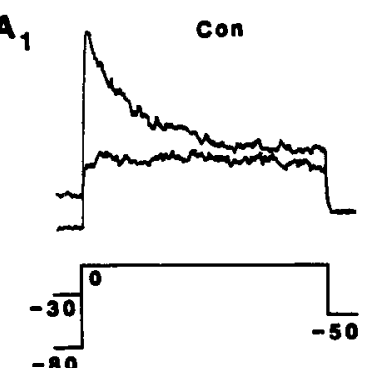

$\mathrm{c}_{1}$
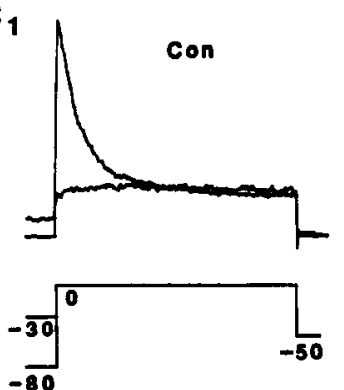

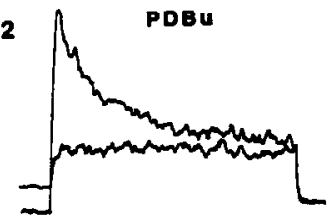

3

$+4-A P$

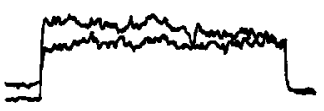

$\coprod_{50}^{75 P A}$

2
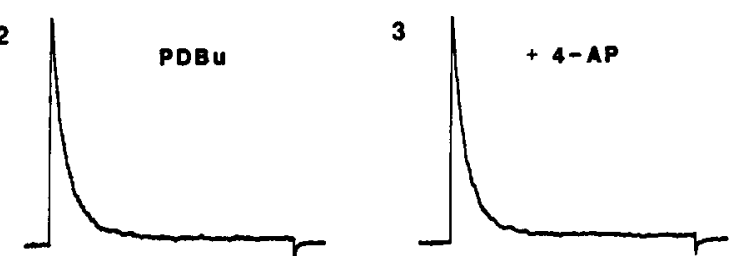
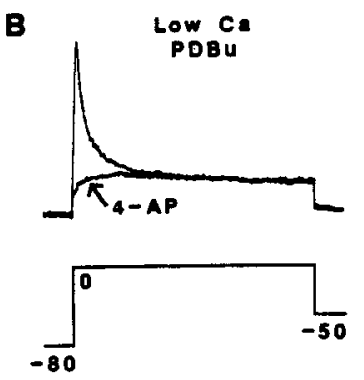

4
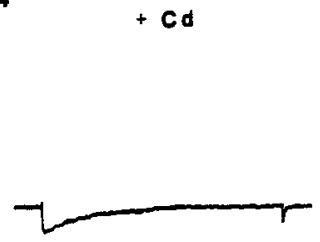

$100 \mathrm{PA}$

Figure 2. Voltage dependence and pharmacology of the PKC-resistant transient outward current. $A$, The PKC-resistant transient current in acutely dissociated neurons closely resembles the " $\mathrm{A}$ " current described in other preparations. In control saline containing $20 \mathrm{mM}$ TEA $(A I)$, the transient was completely inactivated by prepulses to potentials more depolarized than $-40 \mathrm{mV}$ (lower trace). Transient current was unaltered following bath application of $2 \mathrm{~mm}$ PDBu $(A 2)$ but was eliminated by subsequent addition of $2 \mathrm{~mm} 4-\mathrm{AP}$ to the chamber $(A 3)$. $B$, In acutely dissociated neurons, the outward transient persisted in a solution containing $0 \mathrm{Ca}, 2 \mathrm{~mm} \mathrm{Mn}$, and $2 \mu \mathrm{M} \mathrm{PDBu}$ (upper trace) but was blocked by bath application of 2 mM 4-AP (arrow). (Different cell than in A.) The PKC-resistant transient was also unaffected by addition of Cd to the bath (data not shown). $C$, PKC-resistant transient outward current in tissue-cultured neurons is $\mathrm{Ca}$ dependent but insensitive to high doses of 4-AP. Like that in acutely dissociated neurons, transient current recorded in tissue-cultured neurons in the presence of $20 \mathrm{mM}$ TEA was inactivated at depolarized holding potentials $(C 1$, lower trace), and showed a similar resistance to $2 \mu \mathrm{M}$ PDBu (C2). In tissue-cultured neurons, however, the transient was unaffected by bath application of $10 \mathrm{~mm} 4$-AP $(C 3)$. Moreover, subsequent addition of low-dose Cd $(100 \mu \mathrm{M})$ completely eliminated the outward transient, leaving only a $C d$-insensitive $T$-type inward current $(C 4)$.

sociated from juvenile guinea pig or tissue cultured from fetal rat. Data from these preparations were identical, except as noted.

In control conditions, outward currents have both transient and persistent components. Active phorbol esters and OAG produced the same effects on ionic currents in these experiments; therefore, we pooled the data from these PKC activators. Phorbol esters or OAG selectively depress the persistent components $[31.5 \pm 3.3 \%$ reduction (mean \pm SEM)] with negligible effect on the transient component ( $7.5 \pm 1.8 \%$ reduction, $n=43$; Fig. $1 A$ ). The cell in Figure $1 A$ was examined prior to and after (arrow) the addition of $1.5 \mu \mathrm{M}$ PDA to the bath. The $I-V$ relationships from another cell (Fig. $1 B$ ) confirm that persistent outward current was depressed throughout the voltage range examined, whereas transient current was unaffected.

The persistent outward current has both Ca-dependent $\left(I_{\mathrm{K}-\mathrm{Ca}}\right)$ and voltage-dependent but $\mathrm{Ca}$-independent subcomponents. We have found that the $\mathrm{Ca}$-independent persistent current is blocked by 5-10 mM TEA (not shown), in agreement with the recent report of Numann et al. (1987). We will call this current $I_{\mathrm{K}}$, although more experiments will be necessary to identify it conclusively. Both currents were reduced by PKC activators as seen in experiments with and without Cd present to block $I_{\mathrm{K}-\mathrm{Ca}}(n=$ 7; Fig. 1C, see legend). Effects of PKC activators on $\mathrm{K}$ currents were reversible with washing (data not shown).

The transient component of $K$ current seemed likely to correspond to the A current, $I_{\mathrm{A}}$. However, inasmuch as $I_{\mathrm{A}}$ is blocked by PKC action in Hermissenda (Alkon et al., 1986), it was important to establish this point unambiguously in hippocampus. First, we noted that the transient is very voltage sensitive.
For example, it is activated by a step to $0 \mathrm{mV}$ following a hyperpolarizing prepulse to $-80 \mathrm{mV}$ but blocked by a step to $0 \mathrm{mV}$ following a prepulse to $-30 \mathrm{mV}$ (see the traces overlapped in Fig. 2A). Second, the transient is TEA insensitive as also shown by the traces in Figure $2 A$, which were obtained in the presence of $20 \mathrm{mM}$ TEA. Third, the isolated transient is phorbol ester insensitive (Fig. 2A2) and 4-aminopyridine (4-AP) sensitive (Fig. 2A3). Fourth, it is $\mathrm{Cd}$ or $\mathrm{Mn}$ insensitive (Fig. 2B). Thus, its time course, voltage dependence, and distinctive pharmacological profile identify this phorbol ester-insensitive current as $I_{\mathrm{A}}$ (Rogawski, 1984).

Interestingly, although a superficially similar current can be recorded in tissue-cultured neurons, we nevertheless have observed some striking differences between this current and $I_{\mathrm{A}}$ recorded in acutely isolated cells. Figure $2 C$ illustrates these points. The transient $\mathrm{K}$ current in cultured cells shows the same voltage dependence and TEA- (Fig. 2C1) and phorbol-ester-insensitivity (Fig. 2C2) as $I_{\mathrm{A}}$ in acutely isolated cells. However, in tissue-cultured neurons, the transient $\mathrm{K}$ current is markedly less 4-AP sensitive, often being unaffected by 4-AP up to 10 mM (Fig. 2C3). Moreover, in cultured cells the major component of the transient $\mathrm{K}$ current is readily blocked by a low $(100 \mu \mathrm{M})$ concentration of Cd (cf. Fig. 2C4). Thus far, we have not further investigated the marked differences between these 2 superficially similar transient $\mathrm{K}$ currents.

\section{Components of whole-cell calcium currents}

Ca currents are also regulated by PKC activation $(n=76)$. Several tests were used to identify $\mathrm{Ca}$ currents: They were not 
A

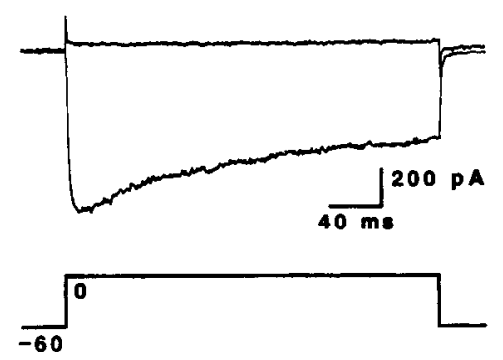

$\mathrm{C}_{1}$

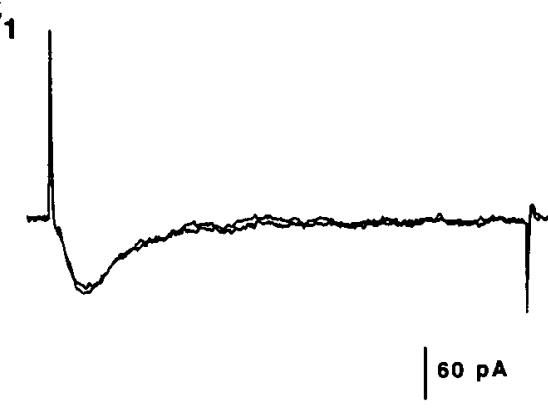

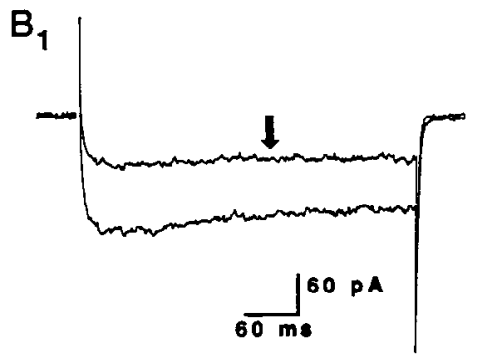

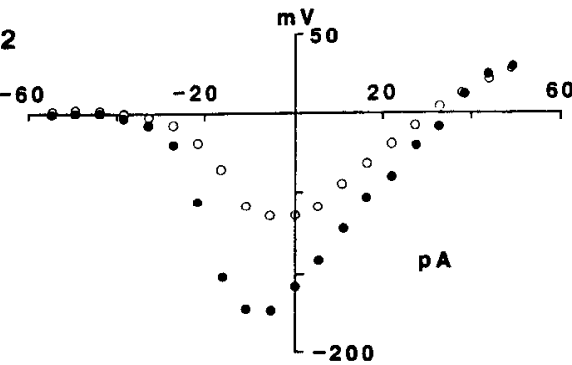

2

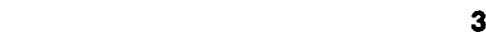

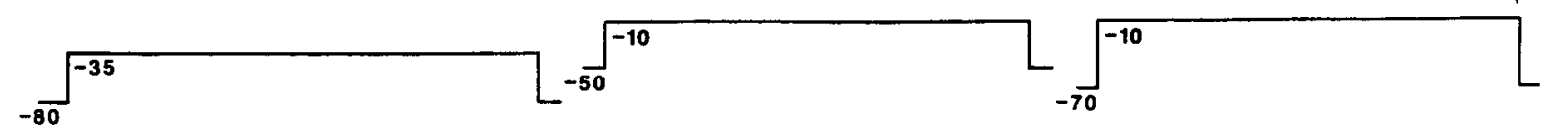

Figure 3. PKC activators selectively decrease high-voltage-activated inward currents. $A$, High-voltage-activated Ba currents were completely blocked by $200 \mu \mathrm{M}$ Cd (upper current trace). The control saline used to record inward currents contained (in $\left.\mathrm{mM}^{2}\right) 145 \mathrm{NaCl}_{1} 10 \mathrm{BaCl}_{2}, 5 \mathrm{CsCl}_{2}, 2$ $\mathrm{MgCl}_{2}, 10$ glucose, $10 \mathrm{HEPES}$, and $0.005 \mathrm{TTX}\left(\mathrm{pH} \mathrm{7.4)}\right.$. $\mathrm{CaCl}_{2}, 5 \mathrm{~mm}$, was substituted for the $\mathrm{BaCl}_{2}$ when low-voltage-activated transient currents were recorded. In all other illustrations, $10 \mathrm{~mm}$ Ba was the charge carrier. $B$, Ba currents elicited by strongly depolarizing clamp steps from a holding potential of $-60 \mathrm{mV}$ were reduced following bath application of $100 \mathrm{nM}$ PDBu $(B 1$, arrow). The reduction was apparent over the entire voltage range with no apparent shift in reversal potential (B2; filled circles, control; open circles, $100 \mathrm{nM} P D B u)$. $C$, A low-voltage-activated transient $\mathrm{Ca}$ current component was evoked in tissue-cultured pyramidal neurons by moderately depolarizing voltage-clamp steps to $-35 \mathrm{mV}$ from a holding potential of $-80 \mathrm{mV} . C 1$, This current was unaltered following bath application of $1 \mu \mathrm{M} \mathrm{PDBu}$. (Traces in control saline and PDBu are superimposed.) Strongly depolarizing clamp steps (to $-10 \mathrm{mV}$ ) from a holding potential of $-50 \mathrm{mV}$ typically evoked slowly inactivating Ca currents in both acutely dissociated and tissue-cultured hippocampal neurons. Bath application of $100 \mathrm{~nm}$ PDBu caused only a slight reduction (arrow) in the slowly inactivating current recorded in the acutely dissociated cell illustrated. Strongly depolarizing clamp steps $(-10 \mathrm{mV})$ from more hyperpolarized levels $(-70 \mathrm{mV})$ elicited large, complex currents with both rapidly and slowly inactivating components. PDBu markedly suppressed this complex current and dramatically slowed inactivation (arrow, $C 3$ ) in the same acutely dissociated neuron as shown in $C 2$.

reduced by TTX or low [Na] saline; they were carried by $\mathrm{Ba}$ and blocked by $\mathrm{Cd}$ (Fig. $3 A$ ).

The Ca current elicited from a step from -60 to $-10 \mathrm{mV}$ was reduced by PDBu (Fig. 3B1, arrow). The $I-V$ relationships from this cell are shown before (Fig. $3 B 2$, filled circles) and after (open circles) PDBu application. The smooth $I-V$ functions indicate that the current was well clamped and was depressed throughout its range of activation, with no apparent change in reversal potential. (The slight rightward shift in the peak of the $I-V$ plot will be discussed below.) With clamp steps $>300 \mathrm{msec}$, our group data indicated decrements of $33.0 \pm 2.7 \%$ in the peak, inactivating current measured at the onset of the depolarizing step and $17.9 \pm 3.1 \%$ in the plateau, slowly inactivating current at the end of the step $(n=43)$. Multiple Ca currents have been described in several cell types, including hippocampus, and it was therefore of interest to determine if the Ca current types were equally sensitive to regulation by PKC activators. $\mathrm{Ca}$ currents having different voltage sensitivities and time courses were revealed by various voltage-clamp protocols. In tissuecultured, but not in acutely dissociated, neurons, a low-amplitude $(40-80 \mathrm{pA})$, rapidly inactivating current was activated by moderate depolarizations from hyperpolarized holding potentials (Fig. 3CI). In both acutely dissociated and tissue-cultured neurons, a large (250-1240 pA), complex current having both rapidly and slowly decaying phases was activated by strong depolarizations from -70 or $-80 \mathrm{mV}$ to potentials above -20 $\mathrm{mV}$ (Fig. $3 C 3$ ), whereas only a smaller (150-310 pA), slowly decaying current was activated by depolarizing steps from relatively depolarized holding potentials of -40 or $-50 \mathrm{mV}$ (Fig. $3 C 2$ ). Thus, $\mathrm{Ca}$ current in hippocampal neurons has "low-voltage"-and "high-voltage"-activated components (Llinás and Yarom, 1981; Carbone and Lux, 1984; Jahnsen and Llinás, 1984; Yaari et al., 1987). Moreover, our whole-cell Ca current profiles correspond to currents carried by T-, L-, and N-type Ca channels in DRG cells (Nowycky et al., 1985). Therefore, we will use the " $\mathrm{T}, \mathrm{L}$, and N" terminology as operational definitions for convenience. Single-channel studies will be necessary to determine if such operationally defined components are, in fact, mediated by distinct channel types.

Disproportionate depression of the peak, rapidly inactivating current, compared with the plateau, slowly inactivating current (see above), suggested that either the T- or the $\mathrm{N}$-type current 

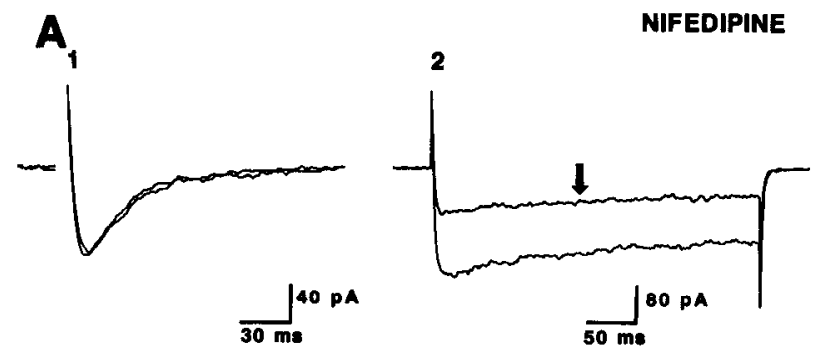

3
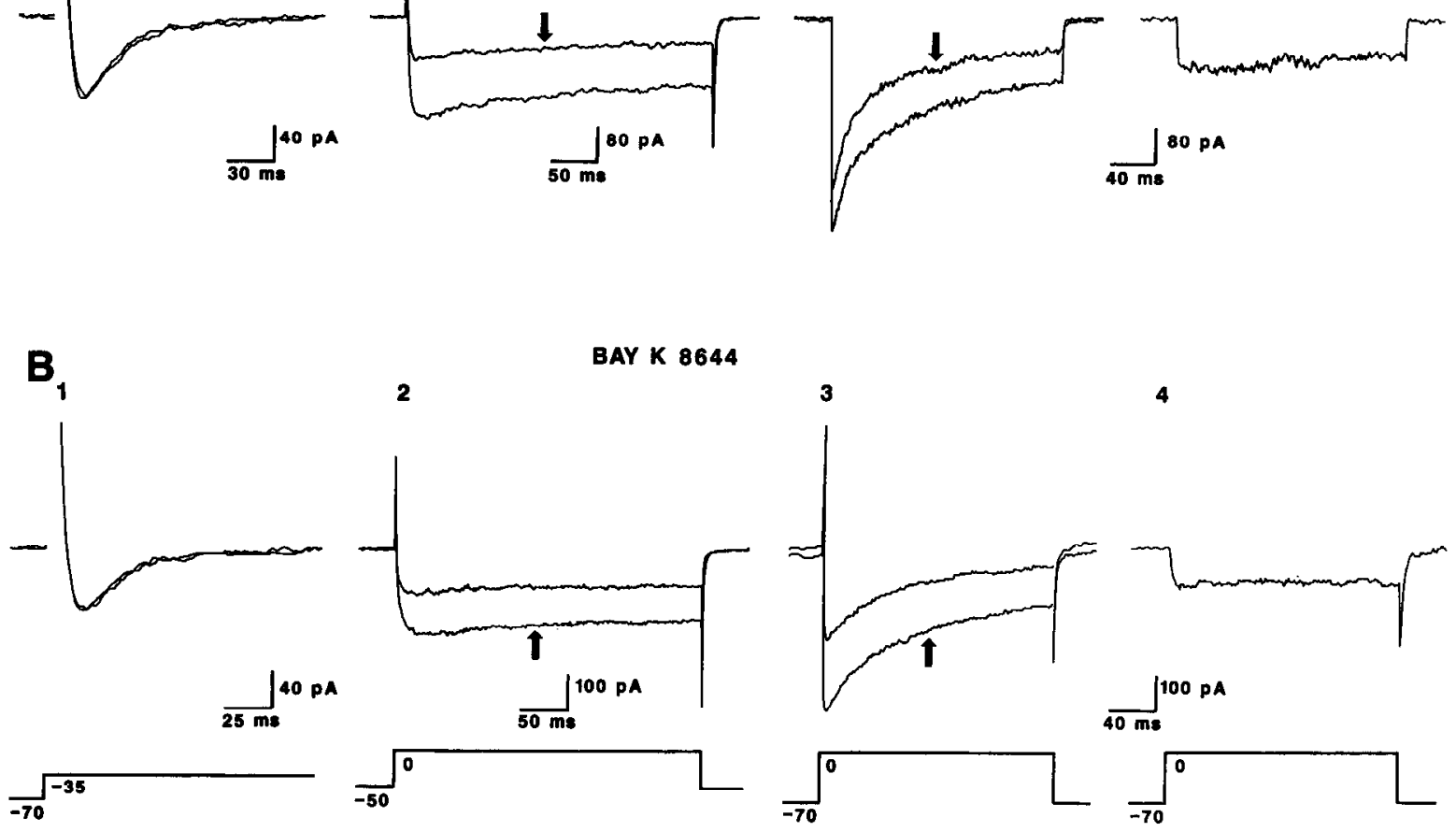

Figure 4. Inward current components correspond to $\mathrm{T}, \mathrm{N}$, and $\mathrm{L}$ currents on the basis of their voltage dependence and sensitivity to dihydropyridines. $A$, Nifedipine. 1, The low-voltage-activated transient $\mathrm{Ca}$ current (T-type) elicited in a tissue-cultured neuron by a moderately depolarizing clamp step from a holding potential of $-75 \mathrm{mV}$ was unaltered following bath application of $50 \mathrm{~nm}$ nifedipine. (Control and nifedipine traces superimposed.) 2, High-voltage-activated persistent Ca current (L-type) was evoked in an acutely dissociated neuron by a strongly depolarizing clamp step from a holding potential of $-50 \mathrm{mV}$. Bath application of $50 \mathrm{nM}$ nifedipine caused a $46 \%$ reduction in L-type current in this cell (arrow). 3 and 4 , A complex current consisting of both $\mathrm{N}$ - and L-type components was evoked in the same neuron as 2 by subjecting the cell to a 1 sec conditioning prepulse to $-70 \mathrm{mV}$, followed by a strongly depolarizing test step (3). Nifedipine, $50 \mathrm{~nm}$ (arrow), caused a $22 \%$ reduction in peak inward current and a $59 \%$ reduction in the current measured at the end of the depolarizing test step. Digital subtraction of the nifedipine trace from the control trace revealed that the current affected by nifedipine was noninactivating (4). B, BAY K 8644. 1 , T-type current recorded in a tissue-cultured neuron was unaltered following bath application of $125 \mathrm{nM}$ BAY K 8644 . (Control and BAY K traces superimposed.) 2 , A $92 \%$ increase in persistent high-voltage-activated (L-type) current recorded in an acutely dissociated cell was observed following bath application of $100 \mathrm{nM}$ BAY K 8644 (arrow). 3 and 4, Complex high-voltage-activated currents were elicited in the same acutely dissociated neuron using a hyperpolarizing prestep as previously described (3). Peak inward current was increased by $66 \%$ in the presence of $100 \mathrm{nM}$ BAY K 8644 , while persistent current measured at the end of the depolarizing test step was increased $138 \%$. Digital subtraction of the control trace from the BAY K trace reveals that the highvoltage-activated current component most affected was noninactivating. Slight increases in the inward current elicited by the conditioning prestep and in the tail current were sometimes observed in the presence of BAY K 8644 . These changes were not accompanied by any change in holding current and probably result from a hyperpolarizing shift in the Ca current-voltage relationship frequently seen following BAY K 8644 application (Gahwiler and Brown, 1987).

was affected more than the L-type current. Using clamp protocols that reveal the $\mathrm{T}$ - and the L-type currents more clearly, we observed directly that the former was unaffected (Fig. 3C1), while the latter was less affected than N-type current by either phorbol esters (Fig. 3C2) or OAG application. Moreover, in acutely dissociated neurons we do not see a T-type component; nevertheless, the rapidly inactivating, $\mathrm{N}$-type current is still predominantly reduced in these cells. In paired comparisons from individual acutely isolated cells, peak inward current evoked by stepping to -10 from $-70 \mathrm{mV}$ was reduced by $51.9 \pm 7.7 \%$, whereas reduction of peak inward current evoked by stepping to -10 from $-50 \mathrm{mV}$ was only $19.0 \pm 9.3 \%(n=7 ; p<0.02)$. We note that these values are conservative estimates of the effect; i.e., we simply measured the total current at the peak. Had we estimated and subtracted the contribution of $L$ to the peak of the high-voltagc-activated current, the relative depression of $\mathrm{N}$ versus $\mathrm{L}$ would have been substantially greater. Hence, it appears that both $\mathrm{N}$ and $\mathrm{L}$ components are regulated by PKC, whereas $\mathrm{T}$ current is not. Moreover, $\mathrm{N}$-type current appears to be a particular target for regulation, although other explanations are possible, as discussed below.

\section{Effects of dihydropyridines}

Dihydropyridine sensitivity is also used to distinguish among the various Ca current types (Rampe et al., 1984; Nowycky et al., 1985; Kamp and Miller, 1987). We tested the effects of the Ca agonist BAY K 8644 and the Ca antagonist nifedipine on the various Ca current components. We found that neither BAY K 8644 nor nifedipine had significant effects on the T-type current.

Nifedipine selectively depressed the L-type current, with much less effect on the N-type current (Fig. $4 A$ ). Similarly, BAY K 8644 markedly enhanced the L-type current, with only slight effects on the N-type current (see Fig. $4 B$ ). Dihydropyridines 
did exhibit complex time and dose dependency, but in general our results are compatible with other reports indicating the existence of 3 separate Ca currents (Miller, 1987).

\section{Effects of PKC activators on Ca currents}

Although it appeared unlikely that increases in an outward current could account for the observed depression of the Ca current, we tested this hypothesis by examining the $\mathrm{Ca}$ current tails recorded at $-70 \mathrm{mV}$ following depolarizing steps to various levels to activate the current. In this case, the influence of ions with equilibrium potentials near $-70 \mathrm{mV}$ will be minimized. Figure 5 illustrates typical results from a cell in which the tail current recorded following a $10 \mathrm{msec}$ step to $-10 \mathrm{mV}$ was significantly reduced in the presence of $\mathrm{PDBu}$ with no change in the time constants of deactivation. The tail current in this case was well fit $(r=0.999)$ by a double exponential with time constants of 0.77 and $6.97 \mathrm{msec}$ before and 0.68 and $6.5 \mathrm{msec}$ after adding PDBu to the bath. The plot of tail current amplitude versus membrane potential indicated a decrease in conductance from 3.2 to $2.0 \mathrm{nS}$. Similar results were obtained from 6 other cells. We have not investigated the relationship between multiple exponential deactivation kinetics and different $\mathrm{Ca}$ current types, but a multiple exponential description of tail currents is considered indicative of multiple $\mathrm{Ca}$ channel types (Matteson and Armstrong, 1986). In any event, our data confirm that an actual decrease in $\mathrm{Ca}$ conductance had occurred.

$\mathrm{Ca}$ currents are notoriously susceptible to "run-down" during prolonged whole-cell recording (Chad and Eckert, 1986). This is an important consideration in the present experiments since the PKC activators depress Ca currents. However, inclusion of $\mathrm{Mg}$-ATP, EGTA, and the protease inhibitor leupeptin in the whole-cell electrode markedly slows the rate of run-down, as does substitution of $\mathrm{Ba}$ for $\mathrm{Ca}$ in the extracellular solution (Chad and Eckert, 1986; Kay and Wong, 1987). As can be seen in Figure $6 A$, run-down can be adequately controlled so that drug effects are readily discernible. Moreover, the effects of PDBu appeared to be completely reversible, assuming a steady background decrease in current of $1-2 \% / \mathrm{min}$, as reported by Kay and Wong (1987).

Our data clearly indicate that PKC activators cause a reduction in Ca current conductance and suggest a greater effect on an inactivating, $\mathrm{N}$-type, component. While the simplest hypothesis would seem to be that $\mathrm{N}$ channels are the subject of regulation, an alternative interpretation would be that the apparent " $N$ " component is an artifact of poor spatial voltage control of the cell. Both theory (Jack et al., 1975) and experiment (Kramer, 1986) indicate that a transient component of Ca current can result from distortions induced by regenerative currents in poorly clamped regions of the cell. If the $\mathrm{N}$ component were an artifact of this type, then our interpretation of the effects of PKC activation would change. We considered 2 possibilities: (1) that reduction in a Ca-independent conductance leads to improved spatial voltage control with reduction in the poorly clamped transient $\mathrm{Ca}$ current following as a result; and (2) that due simply to reduction in the magnitude of $\mathrm{Ca}$ current itself, voltage control of the cell is improved such that the artifactual "transient" disappears.

In the former case, an effect of PKC activators on some conductance other than $\mathrm{Ca}$ would be observed when $\mathrm{Ca}$ current is removed by a perfusion with a low-Ca/Mn- or Cd-containing saline. However, as shown in the example of Figure $6 B$, no changes in "leak" conductance were seen $(n=12)$. Hence, im-

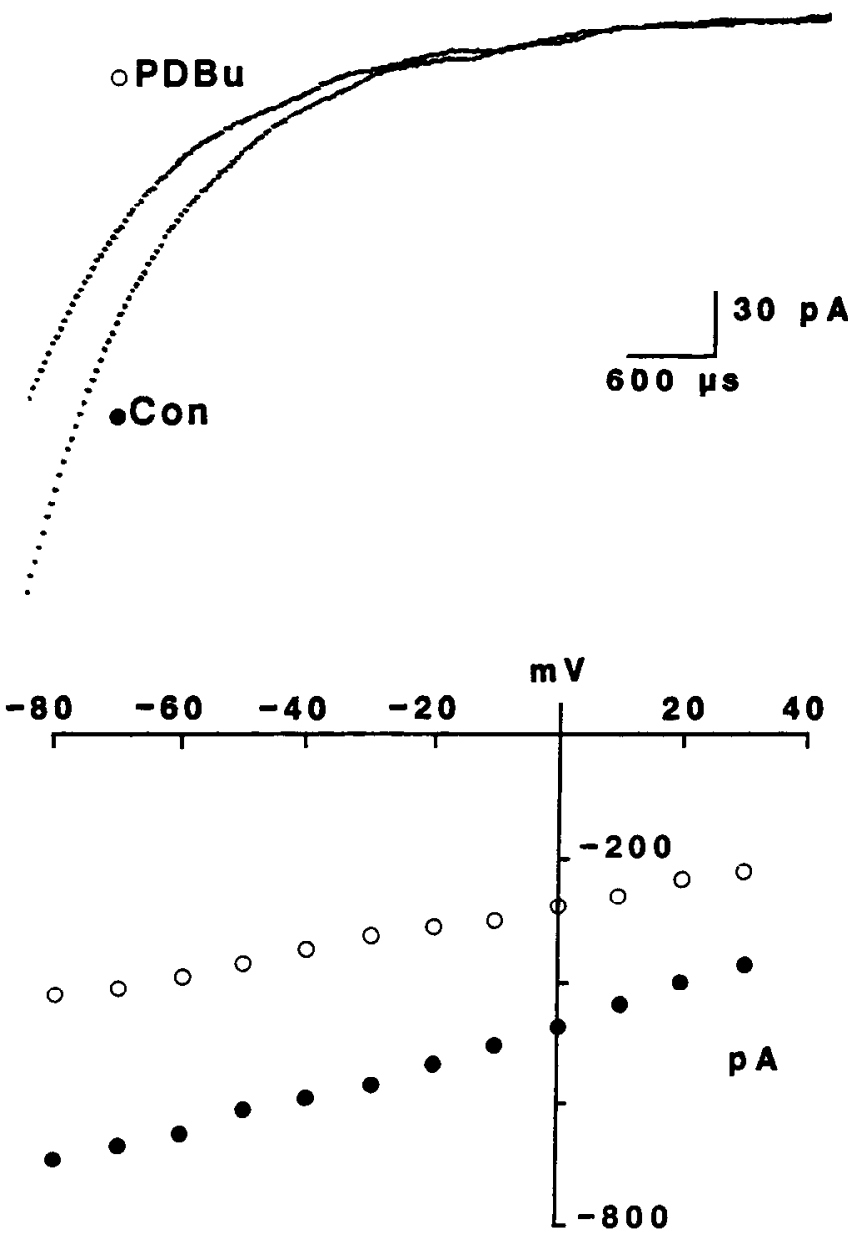

Figure 5. Bath application of PDBu reduced inward tail currents. Tail currents were recorded in an acutely dissociated neuron at $-70 \mathrm{mV}$ following a $10 \mathrm{msec}$ clamp step to $-10 \mathrm{mV}$ before (lower trace) and after (upper trace) $200 \mathrm{nM}$ PDBu application. The time constants of current deactivation, estimated from a double-exponential fit of tail current decay, were unaltered by PDBu (control, 0.77 and $6.97 \mathrm{msec}$; $\mathrm{PDBu}, 0.68$ and $6.5 \mathrm{msec} ; r=0.999$ ). Membrane conductance was estimated from plots of tail current amplitude versus holding membrane potential (lower panel). PDBu application caused a $37 \%$ decrease in conductance in the cell illustrated here.

proved space clamp by this mechanism is unlikely to explain our data.

In the latter case, simple reduction of $\mathrm{Ca}$ current magnitude should lead to disappearance of the $\mathrm{N}$ component, thus mimicking the effects of PKC activators. Reduction of the N component in our experiments was indicated by both a greater decrease in the peak versus the plateau of the $\mathrm{Ca}$ current and a slowed rate of inactivation of the residual current (Fig. $3 C$ and below). Both peak depression and slowed inactivation should be produced by reduction in $\mathrm{Ca}$ current magnitude under this hypothesis. Morcover, the peak of the predictcd $I-V$ rclationship of unclamped, regenerative currents is left-shifted compared with the peak of the $I-V$ curve under perfect clamp control (Jack et al., 1975). An improvement in spatial voltage control would be expected to cause a right shift in the Ca current $I-V$ curve.

In Figure $6 C$, the traces illustrate that the $C a$ current recorded in PDBu, besides being reduced, is significantly slowed. Peak currents were scaled to make this comparison readily visible. To make a quantitative comparison among a group of cells, we 
A

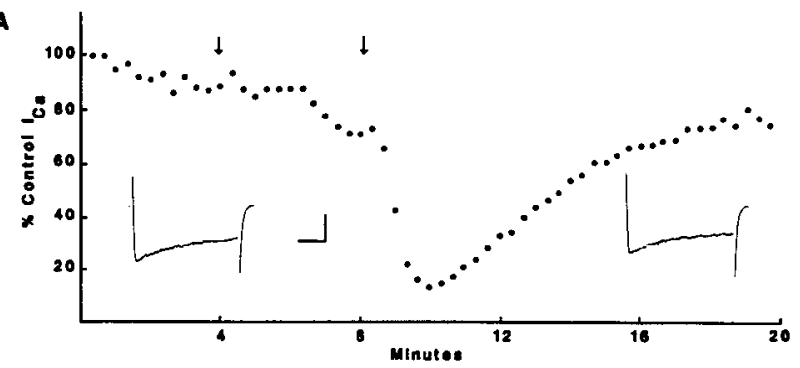

B

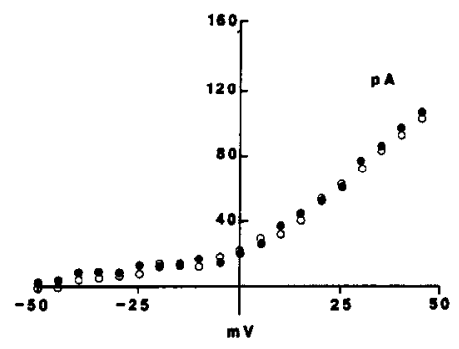

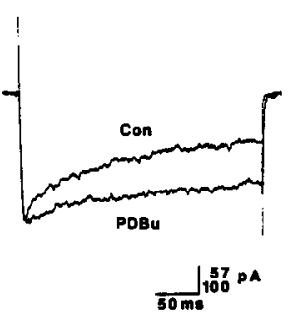

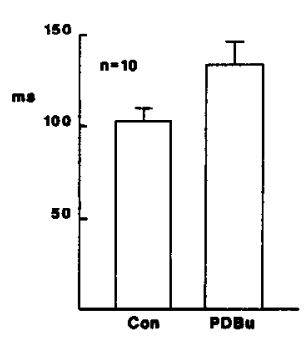

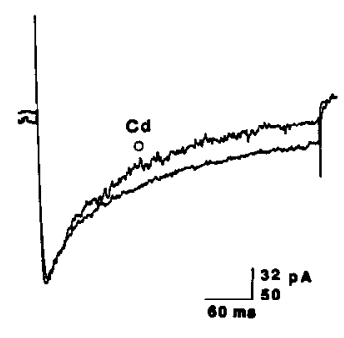

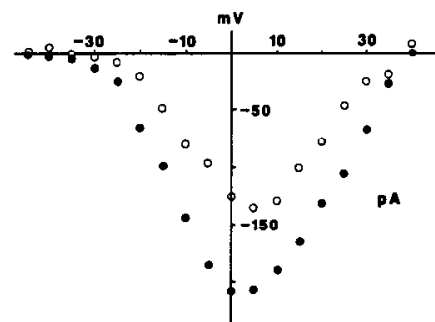

Figure 6. PKC effects are unrelated to current run-down or space clamp considerations. A, Ca current run-down cannot account for depressant effects of PKC activators or inward currents. Ca currents in this tissue-cultured neuron were evoked at 20 sec intervals by depolarizing steps to $-10 \mathrm{mV}$ from a holding potential of $-70 \mathrm{mV}$. Two $100 \mu \mathrm{l}$ boluses of $10 \mu \mathrm{M}$ PDBu were added to the continuously flowing bath perfusate at the arrows (final bath concentration, $500 \mathrm{~nm}$ ). Peak inward current, normalized to an initial control value, is plotted as a function of time. $\Lambda$ lthough the phorbol ester suppression of Ca current was unusually dramatic in this cell, an essentially complete recovery was obtained following $10-15$ min of washing. Apparent discrepancies between control and recovery values are due to steady time-dependent run-down of Ca current. Ca currents had been recorded in this cell for $22 \mathrm{~min}$ prior to the period illustrated. Scale bar, $200 \mathrm{pA}$ (vertical), 50 msec. $B$, Inward current in an acutely dissociated neuron was blocked by bath application of $100 \mu \mathrm{M}$ Cd. Residual "leak" current was unaffected by bath application of PDBu (filled circles, control; open circles, $1 \mu \mathrm{M}$ PDBu). $C$, PKC activators slow Ca current inactivation. Peak inward currents elicited by clamp steps to $0 \mathrm{mV}$ from a holding potential of $-70 \mathrm{mV}$ before and after bath application of $100 \mathrm{nM}$ PDBu were normalized to peak current to demonstrate the effect of PKC activators on the rate of inactivation in a typical cell (left). Time constants of inactivation, estimated from single-exponential fits of current decay, were compared in a group of 10 cells in control saline and following bath application of $100 \mathrm{nM}$ PDBu (right). The mean time constant in the presence of PDBu $(135 \pm 12 \mathrm{msec})$ was significantly slower than the control value $(103 \pm 7 \mathrm{msec})(p<0.02)$. D, Reduction of Ca current amplitude does not alter inactivation kinetics or voltage dependence. Inward currents in control and following addition of $10 \mu \mathrm{M}$ Cd were normalized, and time constants of inactivation were estimated from a single-exponential fit of current decay. Inactivation was slightly faster in the presence of $10 \mu \mathrm{M} \mathrm{Cd}{ }^{2+}$ (upper trace) than in control (see text). A slight (approximately $5 \mathrm{mV}$ ) depolarizing shift in the $I-V$ relationship of this cell (right) was noted in the presence of $\mathrm{Cd}^{2+}$, with no apparent shift in reversal potential (filled circles, control; open circles, $10 \mu \mathrm{M} \mathrm{Cd}$ ).

fit exponential functions to the inactivation phase of the current. In all cases, inactivation was well fit by a single exponential $(r$ $>0.9)$. In many cases inactivation could be fit somewhat better by 2 exponentials; however, in other cases 2 exponentials could not be fit at all. Hence, to make the comparison across a group of cells, we used the time constant of the best single-exponential fit. Note we do this solely to obtain a convenient quantitative measure; we do not intend to imply a mechanism of inactivation. The results obtained from a group of 10 cells tested before and after adding PDBu (Fig. $6 C$ ) to the medium indicated a highly significant $(p<0.02)$ slowing of the time constant of inactivation, from $103 \pm 7.0$ to $135 \pm 12.0 \mathrm{msec}$. If PKC activators work solely by reducing $\mathrm{Ca}$ current magnitude, then $\mathrm{Cd}$, which blocks Ca channels, should also slow inactivation.

We examined cells before and after adding a small amount $(10 \mu \mathrm{M})$ of $\mathrm{Cd}$ to the bathing medium. At this concentration, Cd caused a comparable reduction in pcak amplitude but did not slow the time constant of $\mathrm{Ca}$ current inactivation (control $=115 \pm 10.4 \mathrm{msec} ; \mathrm{Cd}=109 \pm 9.0 \mathrm{msec} ; n=5$; e.g., Fig. $6 \mathrm{C}$ ) Both Cd (Fig. $6 D$, right) and phorbol esters (Fig. 3B2) did cause a slight (approximately $5 \mathrm{mV}$ ) depolarizing shift in the $I-V$ relationship, probably due to improved spatial voltage control. However, the small size of this shift, together with the orderly $1-V$ curves (Figs. $3 B 2$ and $6 D$ ) and well-clamped tail currents (Fig. 5) strongly suggest that these cells are under excellent clamp control. We conclude that the effects of PKC activators cannot be explained as a simple consequence of reduction of Ca current magnitude.

\section{Other evidence for PKC involvement in current depression}

The similarity of effects found using active phorbol and OAG suggests that these effects are due to PKC activation. We performed other experiments to test this hypothesis. Control applications of DMSO $(n=5)$ or saline $(n=6)$ had no effects on either Ca or K currents. Phorbol derivatives of the 4- $\alpha$ form are unable to activate PKC (Blumberg et al., 1984). We found that applications of inactive phorbol esters at concentrations 10 -fold higher than those used for active phorbol esters had no effects on the currents.

As a further test of the hypothesis, we also used identified PKC inhibitors, including $\mathrm{H}-7$ and polymyxin-B. $\mathrm{H}-7$ (40-100 $\mu \mathrm{M})$ increased baseline Ca current in 5 of 7 experiments, although $\mathrm{K}$ currents were unaffected. At $20 \mu \mathrm{M}, \mathrm{H}-7$ did not alter control Ca currents $(n=4)$. H-7 antagonized the depressant effect of phorbol esters or OAG on $\mathrm{Ca}$ and $\mathrm{K}$ currents. Examples of this are shown in Figure 7. In the experiment shown in Figure $7 A$, the depressant effect of $200 \mathrm{~nm}$ PDBu was reversed by 20 $\mu \mathrm{M} \mathrm{H}-7$ within $10 \mathrm{~min}$, despite the continued presence of the phorbol ester. In the absence of the inhibitor, the phorbol esteror OAG-depressed current never spontaneously increased $(n=$ 
A

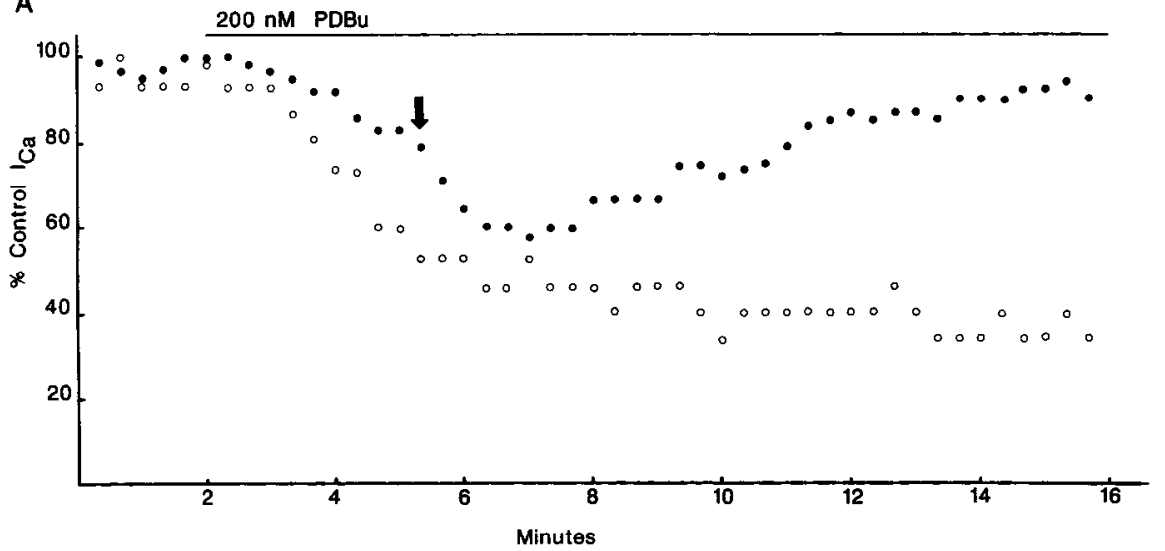

B

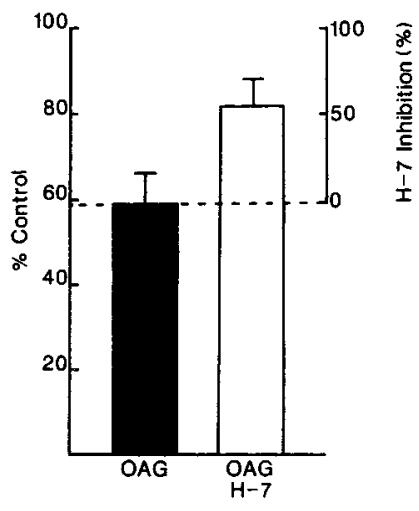

Figure 7. H-7 antagonizes the depressant effects of phorbol esters or OAG. A, Peak Ca currents, evoked at 20 sec intervals in acutely dissociated neurons by $100 \mathrm{msec}$ depolarizing clamp steps to $0 \mathrm{mV}$ from a holding potential of $-70 \mathrm{mV}$, were normalized to initial control values and plotted versus time. Upper trace, Ca currents were rapidly suppressed by bath application of $200 \mathrm{nM}$ PDBu. This effect was reversed within 10 min following bath application of $20 \mu \mathrm{M} \mathrm{H}-7$ (arrow), despite the continued presence of the phorbol ester in the perfusion chamber. Lower trace, In the absence of any PKC inhibitor, phorbol-induced suppression of Ca currents never spontaneously reversed. The typical response of an acutely dissociated neuron to maintained exposure to $200 \mathrm{nM}$ PDBu is shown here. $B$, Persistent $\mathrm{K}$ currents were evoked in tissue-cultured neurons by 700 msec depolarizing clamp steps to $0 \mathrm{mV}$ from a holding potential of $-50 \mathrm{mV}$. Percentage suppression of control current (measured at the end of the depolarizing pulse) was recorded $20 \mathrm{sec}$ after pressure ejection of $60 \mu \mathrm{M}$ OAG (1 sec ejection, $7 \mathrm{psi}$ ) from a blunt micropipette positioned approx. $20 \mu \mathrm{m}$ from the cells. Responses to OAG in normal saline (OAG) are compared with those observed in cells pretreated for $20 \mathrm{~min}$ with $50 \mu \mathrm{M}$ H-7. (Responses were the average of 5 individual applications of OAG to each of 6 cells in both control and H-7 pretreated groups.) In normal saline, OAG application caused a $40.8 \pm 6.8 \%$ reduction in late outward current on the average. In cells pretreated with $\mathrm{H}-7$, an $18.4 \pm 5.7 \%$ reduction in late outward current followed OAG application. Thus, the OAG-induced suppression of persistent $\mathrm{K}$ current was decreased by approximately $55 \%$ in neurons pretreated with $\mathrm{H}-7$ as compared with cells recorded in normal saline.

9; e.g., circles in Fig. 7A). Pretreatment of cells with $50 \mu \mathrm{M} \mathrm{H}-7$ significantly reduced the depressant effect of OAG on K currents (Fig. $7 B ; p<0.05$ ). Polymyxin-B also reversed the phorbol esterdepressed Ca current $(n=4$; data not shown).

Both $\mathrm{H}-7$ and polymyxin-B are thought to inhibit PKC much more potently than they do $\mathrm{Ca} /$ calmodulin-dependent protein kinase in mammalian brain tissue (Greenberg et al., 1987). However, because these agents are not entirely selective, we also tested the $\mathrm{Ca} /$ calmodulin inhibitor calmidazolium. At high doses (10-50 $\mu \mathrm{M})$, calmidazolium had potent depressant effects on Ca currents $(n=5)$. Lower doses $(\leq 500 \mathrm{nM})$, which should nevertheless produce significant inhibition of $\mathrm{Ca} /$ calmodulindependent processes (Greenberg et al., 1987), had no effect on $\mathrm{Ca}$ currents and were completely ineffective in reversing the effects of phorbol esters $(n=8)$.

$\mathrm{H}-7$ is twice as potent in inhibiting cAMP-dependent protein kinase (protein kinase A) as PKC (Hidaka et al., 1984). We observed no inhibition of Ca currents following bath application of 8-bromo cyclic AMP to activate protein kinase A $(n=4)$. Indeed, $\mathrm{Ca}$ currents in the presence of the membrane-permeable cAMP were unusually stable. The ability of $\mathrm{H}-7$ to antagonize the depressant effects of PKC activators is therefore difficult to reconcile with possible inhibition of protein kinase $A$.

\section{Discussion}

Phorbol esters and diacylglycerol can release hormone and other transmitters from secretory elements (Nishizuka, 1984), including nerve terminals (Wakade et al., 1985; Eusebi et al., 1986; Haimann et al., 1987; Malenka et al., 1987; Nichols et al., 1987; Shapira et al., 1987). Because this release can occur in a Caindependent way (Nishizuka, 1984; Malenka et al., 1987), it is not possible in a multicellular preparation such as a brain slice or tissue culture to exclude the possibility that PKC activators have effects that are secondary to release of neurotransmitters or other substances. In the acutely isolated hippocampal neuron, however, this problem is eliminated as the cells are disconnected from presynaptic contacts. Complications due to the restricted extracellular space in organized tissue, e.g., ion accumulation or depletion, are also removed. Our data therefore represent an unambiguous demonstration of the postsynaptic action of phorbol esters and $\mathrm{OAG}$ on $\mathrm{Ca}$ and $\mathrm{K}$ currents.

Data from the hippocampal slice had indicated that phorbol esters blocked a Ca-dependent $\mathrm{K}$ conductance (Baraban et al., 1985; Malenka et al., 1986). Our results confirm this observation in acutely isolated cells. We have extended previous data from the slice by demonstrating for the first time that a persistent current that is similar to $I_{\mathrm{K}}$ is blocked, while the transient current, $I_{\mathrm{A}}$, is resistant to $\mathrm{PKC}$ regulation.

We also show that PKC activation has different effects on various Ca current components in hippocampal neurons. Recent evidence indicates that neurons have multiple types of Ca channels (Llinás and Yarom, 1981; Carbone and Lux, 1984; Jahnsen and Llinás, 1984; Nowycky et al., 1985; Reynolds et al., 1986; Miller, 1987; Yaari et al., 1987). While it has been suggested that they subserve different functions and may be differentially regulated (Miller, 1987), few data bear on this proposition.

We demonstrate for the first time that PKC activation selectively reduces high-voltage-activated $\mathrm{Ca}$ current, without affecting low-voltage-activated, T-type, current. Moreover, the time course of residual high-voltage-activated current is significantly slowed by PKC activators. Two phases of high-voltageactivated current were operationally defined as $\mathrm{L}$ and $\mathrm{N}$ components, and one parsimonious explanation for this slowing is that a genuine, rapidly inactivating $N$ current was reduced. $A$ preliminary report indicates that $\mathrm{T}, \mathrm{N}$, and $\mathrm{L}$ channels do exist in hippocampal CA3 neurons (Bley et al., 1987), and our dihydropyridine data are consistent with the existence of $\mathrm{T}$, $\mathrm{L}$, and 
$\mathrm{N}$ channels. Nevertheless, dihydropyridine actions are notoriously complex and controversial (Bean, 1984; Brown et al., 1984), and we have not directly demonstrated that our N component is actually mediated by $\mathrm{N}$ channels. On the other hand, Kay and Wong (1987) infer from an analysis of current activation kinetics that acutely isolated CA1 neurons possess only a single class of high-voltage-activated $\mathrm{Ca}$ channels. In this case, our $\mathrm{N}$ component might conceivably reflect either an artifact of poor spatial voltage-clamp control or the operation of an inactivation process not detectable when $\mathrm{Ca}$ current is elicited from depolarized membrane potentials. As discussed in the text, the data argue against the idea that the $\mathrm{N}$ current results from poor space clamp or that the effects of PKC activators reflect an improvement in clamp control. The alternative explanation, that PKC activators change the rapid inactivation process that, in essence, defines our $\mathrm{N}$ type component cannot be ruled out at present.

Synaptic transmission in hippocampus is enhanced by phorbol esters (Malenka et al., 1986a, 1987), however, since Ca current is reduced by phorbol esters and OAG, enhancement of evoked release is probably due either to a $\mathrm{Ca}$-independent mechanism or to a net increased $\mathrm{Ca}$ influx that results from block of $I_{\mathrm{K}}$.

Effects produced by prolonged application of phorbol esters to tissue slices are only very slowly reversible (Baraban et al., 1985; Malenka et al., 1986a, b). This might indicate either that the effects themselves are inherently long-lived or that it is difficult to wash these lipophilic compounds from the tissue. We found that ionic current reductions due to brief application of phorbol esters and OAG were readily reversible (e.g., Fig. 3). Hence long duration of phorbol ester effects in slice preparations appears in part to be due to difficulty in removing these compounds, although it remains possible that lasting alterations result from prolonged application. This observation is relevant to studies of long-term potentiation (Akers et al., 1986; Lynch and Bliss, 1986; Malenka et al., 1986a) in suggesting that the mechanisms underlying depression of $\mathrm{Ca}$ and $\mathrm{K}$ current per se are unlikely to account for the long-term increases in excitability.

The effects of PKC activation in hippocampal neurons differ in several ways from its effects in other preparations. Slowly inactivating $\mathrm{Ca}$ current is reduced by $\mathrm{PKC}$ activation in rat DRG cells (Rane and Dunlap, 1986), cultured mouse neurons (Werz and Macdonald, 1987), and snail neurons (Hammond et al., 1987). A similar current is enhanced in Aplysia (DeRiemer et al., 1985) and Hermissenda (Alkon et al., 1986; Farley and Auerbach, 1986). In Aplysia, K currents are not affected, while in Hermissenda, $I_{\mathrm{A}}$ is a target for PKC regulation and $I_{\mathrm{K}}$ is not affected. In hippocampus, $I_{\mathrm{A}}$ is unaffected while $I_{\mathrm{K}}$ is blocked. Phorbol esters block $\mathrm{M}$-current in neuroblastoma cell lines (Higashida and Brown, 1986) but not in the hippocampus (Malenka et al., 1986b). $I_{\mathrm{K}-\mathrm{Ca}}$, on the other hand, is suppressed by PKC activators in a number of systems (Baraban et al., 1985; Freedman and Aghajanian, 1985; Alkon et al., 1986; Farley and Auerbach, 1986; Malenka et al., 1986b). In tissue-cultured central neurons, $I_{\mathrm{K}}$ is also reduced (Grega et al., 1987), but $I_{\mathrm{A}}$ and $I_{\mathrm{K}-\mathrm{Ca}}$ were not analyzed in those cells. In hippocampus, depression of $I_{\mathrm{K}-\mathrm{Ca}}$ may be partly accounted for by depression of $I_{\mathrm{Ca}}$. However, the membrane hyperpolarization caused by $I_{\mathrm{K} . \mathrm{Ca}}$ is far more sensitive to blockade by phorbol esters than the Ca action potential (Baraban et al., 1985; Malenka et al., 1986b), so a direct effect on $\mathrm{Ca}$-dependent $\mathrm{K}$ conductances is also possible. Since these currents influence neuronal excitability in a variety of ways, it seems that PKC must subserve a variety of functions in different species.

Adenosine reduces the $\mathrm{N}$-like component of $\mathrm{Ca}$ current in hippocampal neurons in culture (Madison et al., 1987). Activators of PKC also depress this component, and it is natural to wonder whether they and adenosine share a common site of action. An interesting possibility for this site would be a $G$ protein. $G$ proteins mediate transmitter-induced depression of Ca current in other cells (Holz et al., 1986; Scott and Dolphin, 1986; Herscheler et al., 1987). A G protein serves as a substrate for $\mathrm{PKC}$ phosphorylation in platelets; the $\mathrm{G}$ protein regulating $I_{\mathrm{Ca}}$ in brain may be a substrate for PKC, or, conversely, PKC may be regulated by a $\mathrm{G}$ protein. Interestingly, phorbol esters, and muscarinic agonists that cause PI turnover, block the ability of adenosine to activate a $\mathrm{K}$ conductance in hippocampal neurons (Worley et al., 1987) and oocytes (Dascal et al., 1985). An adenosine-induced increase in $\mathrm{K}$ conductance is also mediated by a $G$ protein (Trussel and Jackson, 1986). Further investigation of the interactions between $\mathrm{PKC}$ activation and regulation of G-protein-linked neurotransmitter actions should prove rewarding.

\section{References}

Akers, R. F., D. M. Lovinger, P. A. Colley, D. J. Linden, and A. Routtenberg (1986) Translocation of protein kinase C activity may mediate hippocampal long-term potentiation. Science 231: 587-589.

Alkon, D. L., M. Kubota, J. T. Neary, S. Naito, D. Coulter, and H. Rasmussen (1986) C-kinase activation prolongs $\mathrm{Ca}^{2+}$-dependent inactivation of $\mathrm{K}^{+}$currents. Biochem. Biophys. Res. Commun. 134: 1245-1253.

Baraban, J. M., S. H. Snyder, and B. E. Alger (1985) Protein kinase $\mathrm{C}$ regulates ionic conductance in hippocampal pyramidal neurons: Electrophysiological effects of phorbol esters. Proc. Natl. Acad. Sci. USA 82: 2538-2542.

Bean, B. P. (1984) Nitrendipine block of cardiac calcium channels: High-affinity binding to the inactivated state. Proc. Natl. Acad. Sci. USA 81: 6388-6392.

Bley, K. R., D. V. Madison, and R. W. Tsien (1987) Multiple types of calcium channels in hippocampal neurons: Characterization and localization. Soc. Neurosci. Abstr. 13: 1010

Blumberg, P. M., S. Jaken, B. Konig, N. A. Sharkey, K. L. Leach, A. Y. Jeng, and E. Yeh (1984) Mechanism of action of the phorbol ester tumor promoters: Specific receptors for lipophilic ligands. Biochem. Pharmacol. 33: 933-940.

Brown, A. M., D. L. Kunze, and A. Yatani (1984). The agonist effect of dihydropyridines on Ca channels. Nature 311: 570-572.

Carbone, E., and H. D. Lux (1984) A low voltage-activated calcium conductance in embryonic chick sensory neurons. Biophys. J. 46:413418.

Castagna, M., Y. Takai, K. Kaibuchi, K. Sano, U. Kikkawa, and Y. Nishizuka (1982) Direct activation of calcium-activated, phospholipid-dependent protein kinase by tumor-promoting phorbol esters. J. Biol. Chem. 257: 7847-7851.

Chad, J. E., and R. Eckert (1986) An enzymatic mechanism for calcium current inactivation in dialyzed Helix neurones. J. Physiol. (Lond.) 378: $31-51$.

Dascal, N., I. Lotan, B. Gillo, H. A. Lester, and Y. Lass (1985) Acetylcholine and phorbol esters inhibit potassium currents evoked by adenosine and cAMP in Xenopus oocytes. Proc. Natl. Acad. Sci. USA 82: 6001-6005.

DeRiemer, S. A., J. A. Strong, K. A. Albert, P. Greengard, and L. K. Kaczmarek (1985) Enhancement of current in Aplysia neurones by phorbol ester and protein kinase C. Nature 313: 313-315.

Eusebi, F., M. Molinaro, and C. G. Caratsch (1986) Effects of phorbol ester on spontaneous transmitter release at frog neuromuscular junction. Pfluegers Arch. 406: 181-183.

Farley, J., and S. Auerbach (1986) Protein kinase C activation induces conductance changes in Hermissenda photoreceptors like those seen in associative learning. Nature 319: 220-223.

Freedman, J. E., and G. K. Aghajanian (1985) Phorbol esters and 
alphal-adrenoceptors: Differing effects on outward currents in rat dorsal raphe neurons. Soc. Neurosci. Abst. 11: 1044.

Greenberg, D. A., C. L. Carpenter, and R. O. Messing (1987) Interaction of calmodulin inhibitors and protein kinase $\mathrm{C}$ inhibitors with voltage-dependent calcium channels. Brain Res. 404: 401-404.

Grega, D. S., M. A. Werz, and R. L. Macdonald (1987) Forskolin and phorbol esters reduce the same potassium conductance of mouse neurons in culture. Science $235:$ 345-348.

Gross, R. A., and R. L. Macdonald (1987) Dynorphin A selectively reduces a large transient ( $\mathrm{N}$-type) calcium current of mouse dorsal root ganglion neurons in cell culture. Proc. Natl. Acad. Sci. USA 84: 5469-5473.

Haimann, C., J. Meldolesi, and B. Ceccarelli (1987) The phorbol ester, 12-O-tetradecanoyl-phorbol-13-acetate, enhances the evoked quanta release of acetylcholine at the frog neuromuscular junction. Pfluegers Arch. 408: 27-31.

Hamill, O. P., A. Marty, E. Neher, B. Sakmann, and F. J. Sigworth (1981) Improved patch-clamp techniques for high-resolution current recording from cells and cell-free membrane patches. Pfluegers Arch. 391: 85-100.

Hammond, C., D. Paupardin-Tritsch, A. C. Nairn, P. Greengard, and H. M. Gerschenfeld (1987) Cholecystokinin induces a decrease in $\mathrm{Ca}^{2+}$ current in snail neurons that appears to be mediated by protein kinase C. Nature 325: 809-811.

Hescheler, J., W. Rosenthal, W. Trautwein, and G. Schultz (1987) The GTP-binding protein, Go, regulates neuronal calcium channels. Nature 325: 445-447.

Hidaka, H., M. Inagaki, S. Kawamoto, and S. Yasuharu (1984) Isoquinolinesulfonamides, novel and potent inhibitors of cyclic nucleotide dependent protein kinase and protein kinase C. Biochemistry 23 . $5036-5041$

Higashida, H., and D. A. Brown (1986) Two polyphosphatidylinositide metabolites control two $\mathrm{K}^{+}$currents in a neuronal cell. Nature 323: 333-335.

Holz, G. G., IV, S. G. Rane, and K. Dunlap (1986) GTP-binding proteins mediate transmitter inhibition of voltage-dependent calcium channels. Nature 319: 670-672.

Huguenard, J. R., and B. E. Alger (1986) Whole-cell voltage-clamp study of the fading of GABA-activated currents in acutely dissociated hippocampal neurons. J. Neurophysiol. 56: 1-18.

Jack, J. J. B., D. Noble, and R. W. Tsien (1975) Electric Current Flow in Excitable Cells, pp. 379-435, Oxford U. P., Oxford.

Jahnsen, H., and R. Llinás (1984) Ionic basis for the electroresponsiveness and oscillatory properties of guinea-pig thalamic neurones in vitro. J. Physiol. (Lond.) 349: 227-247.

Kamp, T. J., and R. J. Miller (1987) Voltage-sensitive calcium channels and calcium antagonists. ISI Atlas of Science: Pharmacology 1 : 133-138.

Kay, A. R., and R. K. S. Wong (1986) Isolation of neurons suitable for patch-clamping from adult mammalian central nervous systems. J. Neurosci. Methods 16: 227-238.

Kay, A. R., and R. K. S. Wong (1987) Calcium current activation kinetics in pyramidal neurones of the CA1 region of the mature guinea pig hippocampus. J. Physiol. (Lond.) 392: 603-616.

Kramer, R. H. (1986) Axonal contribution to subthreshold currents in Aplysia bursting pacemaker neurons. Cell. Mol. Neurobiol. 6:239253.

Kuo, J. F., R. G. G. Andersson, B. C. Wise, L. Mackerlova, I. Salomonsson, N. L. Brackett, N. Katoh, M. Shoji, and R. W. Wrenn (1980) Calcium-dependent protcin kinasc: Widespread occurrence in various tissues and phyla of the animal kingdom and comparison of effects of phospholipid, calmodulin, and trifluoperazine. Proc. Natl. Acad. Sci. USA 77: 7039-7043.

Llinás, R., and Y. Yarom (1981) Properties and distribution of ionic conductances generating electroresponsiveness of mammalian inferior olivary neurones in vitro. J. Physiol. (Lond.) 315: 569-584.

Lynch, M. A., and T. V. P. Bliss (1986) Long-term potentiation of synaptic transmission in the hippocampus of the rat; effect of calmodulin and oleoyl-acetyl-glycerol on release of [3H]glutamate. Neurosci. Lett. 65: 171-176.
Madison, D. V., A. P. Fox, and R. W. Tsien (1987) Adcnosinc reduces an inactivating component of calcium current in hippocampal CA3 neurons. Biophys. J. 51:30a.

Malenka, R. C., D. V. Madison, and R. A. Nicoll (1986a) Potentiation of synaptic transmission in the hippocampus by phorbol esters. $\mathrm{Na}$ ture 321: $175-177$.

Malenka, R. C., D. V. Madison, R. Andrade, and R. A. Nicoll (1986b) Phorbol esters mimic some cholinergic actions in hippocampal pyramidal neurons. J. Neurosci. 6: 475-480.

Malenka, R. C., G. S. Ayoub, and R. A. Nicoll (1987) Phorbol esters enhance transmitter release in rat hippocampal slices. Brain Res. 403: 198-203.

Matteson, D. R., and C. M. Armstrong (1986) Properties of two types of calcium channels in clonal pituitary cells. J. Gen. Physiol. 87: 161182.

Miller, R. J. (1987) Multiple calcium channels and neuronal function. Science 235: 46-52.

Nichols, R. A., J. W. Haycock, J. K. T. Wang, and P. Greengard (1987) Phorbol ester enhancement of neurotransmitter release from rat brain synaptosomes. J. Neurochem. 48: 615-621.

Nishizuka, Y. (1984) Turnover of inositol phospholipids and signal transduction. Science 225: 1365-1370.

Nowycky, M. C., A. P. Fox, and R. W. Tsien (1985) Three types of neuronal calcium channel with different calcium agonist sensitivity. Nature 316: 440-443.

Numann, R. E., W. J. Wadman, and R. K. S. Wong (1987) Outward currents of single hippocampal cells obtained from the adult guineapig. J. Physiol. (Lond.) 393: 331-354.

Rampe, D., R. A. Janis, and D. J. Triggle (1984) BAY K 8644, a 1,4dihydropyridine $\mathrm{Ca}^{2+}$ channel activator: Dissociation of binding and functional effects in brain synaptosomes. J. Neurochem. 43: 16881692.

Rane, S. G., and K. Dunlap (1986) Kinase C activator 1,2-oleoylacetylglycerol attenuates voltage-dependent calcium current in sensory neurons. Proc. Natl. Acad. Sci. USA 83: 184-188.

Reynolds, I. J., J. A. Wagner, S. H. Snyder, S. A. Thayer, B. M. Olivera, and R. J. Miller (1986) Brain voltage-sensitive calcium channel subtypes differentiated by omega-conotoxin fraction GVIA. Proc. Natl. Acad. Sci. USA 83: 8804-8807.

Rogawski, M. A. (1984) The A-current: How ubiquitous a feature of excitable cells is it. Trends Neurosci. 8: 214-219.

Scott, R. H., and A. C. Dolphin (1986) Regulation of calcium currents by a GTP analogue: Potentiation of (-)-baclofen-mediated inhibition. Neurosci. Lett. 69: 59-64.

Segal, M. (1983) Rat hippocampal neurons in culture: Responses to electrical and chemical stimuli. J. Neurophysiol. 50: 1249-1264.

Shapira, R., S. D. Silberberg, S. Ginsburg, and R. Rahamimoff (1987) Activation of protein kinase $\mathrm{C}$ augments evoked transmitter release. Nature 325: 58-60.

Strong, J. A., A. P. Fox, R. W. Tsien, and L. K. Kaczmarek (1987) Stimulation of protein kinase $\mathrm{C}$ recruits covert calcium channels in Aplysia bag cell neurons. Nature 325: 714-717.

Trussel, L. O., and M. B. Jackson (1986) A GTP-binding protein mediates an adenosine-activated $\mathrm{K}^{+}$current independently of cAMP. Soc. Neurosci. Abstr. 12: 15.

Wakade, A. R., R. K. Malhotra, and T. D. Wakade (1985) Phorbol ester, an activator of protein kinase $C$, enhances calcium-dependent release of sympathetic neurotransmitter. Naunyn Schmiedeberg's Arch. Pharmacol. 331: 122-124.

Werz, M. A., and R. L. Macdonald (1987) Dual actions of phorbol esters to decrease calcium and potassium conductances of mouse neurons. Neurosci. Lett. 78: 101-106.

Worley, P. F., J. M. Baraban, M. McCarren, S. H. Snyder, and B. E. Alger (1987) Cholinergic phosphatidylinositol modulation of inhibitory, $\mathrm{G}$ protein-linked, neurotransmitter actions: Electrophysiological studies in rat hippocampus. Proc. Natl. Acad. Sci. USA 84: $3467-$ 3471.

Yaari, Y., B. Harmon, and H. D. Lux (1987) Development of two types of calcium channels in cultured mammalian hippocampal neurons. Science 235: 680-682. 